УДК 008.2:316.324.8

DOI 10.35423/2078-8142.2019.3-4.03

П. М. Сухорольський, кандидат юридичних наук, дочент, доиент кафедри міжнародної інформаиії, Національний університет «Львівська політехніка» м. Львів, Україна e-mail:sukhorolsky@lp.edu.ua ORCID: https://orcid.org/0000-0002-1689-3283

\title{
УТОПІЧНІ ЕЛЕМЕНТИ ПОСТІНДУСТРІАЛЬНИХ ТЕОРІЙ: ІЛЮЗІї ТА СУПЕРЕЧНОСТІ
}

Розроблені у 1970-1980 рр. постіндустріальні теорї продовжують зберігати свій вплив $і$ значущість для наукових досліджень, прийняття політичних рімень та формування домінантних у суспільстві уявлень про майбутнє. Водночас, поза увагою часто залишаються суперечності, закладені в основі ичих теорій, та їхній неоднорідний зміст. Розвинутий у статті підхід розглядає постіндустріалізм як результат поєднання критичного аналізу суспільних процесів, щзо властиві минулому і теперішньому, з ідеологічними компонентами та образами майбутнього, котрі мають явні ознаки утопії. Виокремлення утопічних елементів із найвідоміших концепцій постіндустріального та інформаційного суспільства дає змогу зробити висновок про їхній тісний зв'язок із сочіалістичними і технологічними утопіями доіндустріальної та індустріальної епох. Головні особливості постіндустріальної утопї зумовлені намаганнями ї авторів узгодити власний ідеальний образ майбутнього, щзо радикально відрізняється від індустріальної дійсності, із притаманним індустріалізму лінеарним метапатерном та ідеєю безальтернативного прогресу.

Ключові слова: постіндустріалізм, інформаційне суспільство, Третя хвиля, утопія, ідеологія, образ майбутнього, безальтернативність. 
Постіндустріальні теорії набули популярності, починаючи 3 1970-х років та поступово почали виконувати роль своєрідної призми для оцінки людьми навколишньої дійсності. Вони стверджують швидкий перехід цивілізації до якісно нового стану і позначають нове суспільство словами інформаційне, постіндустріальне, програмоване, мережеве та ін. Незважаючи на назви, для усіх відповідних авторських концепцій спільними є критика та констатація завершення індустріальної епохи, яка тривала близько двох століть, починаючи з часів промислової революції.

Постіндустріалізм має давні корені та вже тривалу історію взаємодії з реальністю, а отже, аж ніяк не може вважатися чимось новітнім та інноваційним у сучасному світі. Основні елементи його критики були виокремлені та озвучені ще 30-40 років тому. Однак відтоді він став чимось значно більшим, ніж просто одна 3 теорій, що намагається пояснити поступ розвитку цивілізації, перетворившись на домінантну парадигму для наукових досліджень, обгрунтування для політики, рішень і дій та міцно вкоренившись у свідомості людей. Безперечно, цьому сприяли як відповідність постіндустріальних теорій духу часу, так і творчий підхід та вміння зауважити ключові тренди, продемонстровані їхніми авторами. Водночас, некритичне ставлення до постіндустріалізму у теперішній час може бути пов'язаним зі свідомими викривленнями та маніпуляціями на догоду конкретним інтересам, або ж помилками й ілюзіями, які перешкоджають тверезому погляду на процеси у сьогоднішньому світі. Усе це змушує вчергове звернути увагу на класичні постіндустріальні теорії, проаналізувати їхній зміст та оцінити їхню виправданість із урахуванням реалій нашого часу.

В основу цього дослідження покладені методологічні підхо$\partial u$, притаманні сучасній футурології (Futures Studies). Насамперед, йдеться про розуміння іiі мети як дослідження трьох головних компонентів - можливих, правдоподібних та бажаних варіантів майбутнього [16, с. 73], а також зосередження на вивченні впливу образів майбутнього на суспільство [22]. Крім цього, базовим є викладений у низці праць підхід $[6 ; 15 ; 24]$, який розглядає різноманітні постіндустріальні концепції як поєднання критичного аналізу дійсності (передусім, індустріальної) із компонентами, що містять ознаки утопії та ідеології. Саме названі утопічні елементи є основ- 
ним предметом нашого дослідження, яке передбачає їх виокремлення та визначення їхнього місця у межах тривалої історії європейської утопічної думки. Ще однією особливістю є виокремлення ролі лінеарного метапатерну прогресу, що $є$ засадничим для постіндустріалізму. Це, з одного боку, дає можливість краще зрозуміти сутність останнього, а 3 іншого - виявити закладені в ньому внутрішні суперечності.

3 урахуванням усього цього, основними завданнями статті є: 1) охарактеризувати значення утопії для розвитку суспільства і цивілізації; 2) довести наявність утопічних, а також ідеологічних компонентів у межах постіндустріальних теорій; 3) визначити загальні особливості постіндустріальної утопії; 4) виокремити властиві постіндустріалізму позиції, що стосуються засад організації суспільства, цінностей, економіки, політики майбутнього, які мають ознаки утопії, а також зробити висновок про перспективи їхнього втілення.

Обрані для дослідження постіндустріальні концепції викладені у впливових наукових та науково-популярних працях, що зробили всесвітньовідомими їхніх авторів та перетворили їх на «класиків постіндустріалізму» (Д. Белл, А. Турен, Й. Масуда, Е. Тоффлер, Дж. Нейсбіт). Важливою основою дослідження є теоретичні праці, присвячені вивченню утопії та ідеології, авторства К. Мангайма, П. Рікера, Ф. Полака та ін. Для встановлення коренів утопічних елементів постіндустріальних теорій використано твори Платона, Т. Мора, Т. Кампа-нелли, Ф. Бекона, В. Морpica, А. Кумарасвамі, А. Пенті тощо. Основи дослідження постіндустріальних утопій закладені у працях К. Вогта, К. Кумара, Д. Лайона, Б. Франкела.

\section{Особливості та історичне значення утопії}

Творення людиною утопій, тобто образів ідеального майбутнього, продовж багатьох століть $є$ неодмінною складовою розвитку цивілізації. Вони є важливим джерелом усіх наук про суспільство та безпосереднім попередником футурології у справі конструювання бажаного світу. Наблизитися до розуміння суспільної ролі утопії допомагає концепція К. Мангайма. Для філософа утопія $є$ неодмінною передумовою розвитку, елементом діалектичного

Institute of Philosophy of H. S. Skovoroda of NAS of Ukraine 
співвідношення між нею і буттям. Утопія руйнує основи існуючого ладу та зумовлює творення нової стадії буття, яка також свого часу буде зруйнована новими утопіями [7, с. 216]. Головним конкурентом утопії є ідеологія. Вони взаємно поборюють одна одну, хоча й мають чимало спільних рис. Критерієм для їх розрізнення $є$ наближеність до влади та ставлення до існуючих порядків - ідеологія укріплює, легітимізує чинний лад, тоді як утопія намагається його зруйнувати. Розвиваючи ці самі ідеї, П. Рікер відзначає такі головні ознаки утопії: фантазія, пошук побічних можливостей, дистанціювання від культурної системи, інколи - втеча від реальності [12, с. 26, 373].

Ідеологія намагається знищити вітальну силу утопії, вона зображає іiі нереальною та пустою. Тому не дивно, що у скованій ідеологією свідомості утопічність означає нездійсненність та пов'язана з численними негативними конотаціями. Утопію намагається побороти не лише ідеологія, а й інші утопії, однак це протистояння не призводить до знищення утопічного елемента загалом, на відміну від випадку, коли утопію атакують із неутопічних позицій [7, с. 265]. Постає питання: чи можна обійтися у теперішньому світі без утопії, поклавшись винятково на раціональність та точні знання? Ствердно відповісти можна лише за умови, якщо ми одночасно визнаємо, що людство вже досягнуло остаточної стадії розвитку, своєрідного «кінця історії», за яким нічого кращого чи якісно іншого не існує, а усі вади теперішнього можна подолати за допомогою «косметичних ремонтів» без фундаментальної зміни основ. Проте тоді доведеться закрити очі й на численні факти ідеологічних спотворень, які замасковані під нібито наукові інтерпретації засад суспільної організації. Для того, щоб уникнути такої однобокості, звернемо особливу увагу на позиції, що обгрунтовують особливу роль утопії для цивілізації.

У згаданому контексті привертає найбільший інтерес теорія одного із засновників сучасної футурології голландського соціолога Ф. Полака про першочергове значення образів майбутнього, які домінують у суспільстві, для його подальшого розвитку. Упродовж останніх кількох століть саме утопія була вмістилищем тих образів, які рухали західну цивілізацію уперед. Вона виконувала роль: 1) буфера для ідей щодо майбутнього; 2) рушійної сили для змін; 
3) тригера суспільного прогресу. Двадцяте століття стало часом тотального занепаду утопічного мислення, - як наслідок утворився вакуум, який заповнюється міфами, ідеологією та псевдоесхатологією [22, с. 179]. Така деутопізація супроводжується поширенням контрутопій у вигляді: 1) дисутопій - демонструють жахливі образи Іншого і тим самим вихвалятимуть існуюче, яке у порівнянні видається не таким уже й поганим; 2) псевдоутопій - покладаються на закони, які вже зараз функціонують; 3) напівутопій - продовжують існуючі тренди та покладаються на науку і планування; 4) негативних утопій - доведених до крайнощів утопій, що є, насправді, карикатурами на них [22, с. 189-191].

Справжній утопії, що має життєву силу та здатна зрушити цивілізацію з місця, притаманні такі властивості як: творчий характер, аристократичність (тобто покладання на свідомий вольовий відповідальний вибір між різними альтернативами), здатність надихати, звернення до емоцій та почуттів заради утвердження нових ідеалів. Вона створює напруження між реальним навколишнім світом та уявним світом Іншого, і саме цей дуалізм $є$ головною передумовою прогресу. Зникнення життєздатної утопії у теперішню епоху Ф. Полак пов'язує, насамперед, із: 1) дефутуризацією, що означає концентрацію на теперішніх проблемах та утвердження реалізму; 2) дедуалізацією, коли згаданий дуалізм під впливом природничих наук вироджується у монізм - залишається тільки реальність, «те, що є», але зникає «те, що має бути»; 3) дегуманізацією, тобто вірою у технології і систему, за якими не видно людини [22, с. 194-198].

Утім, роль утопії не вичерпується їі значенням для творення майбутнього. Крім цього, вона збагачує цивілізацію новими зразками соціальної творчості та неординарного мислення. Це робить їі привабливим об'єктом для вивчення у межах збалансованих освітніх систем, зорієнтованих на розвиток особистості. Не менш важливо й те, що через утопію ми пізнаємо навколишній світ, оскільки вона дає нам змогу дистанціюватися від реальності і подивитися на неї дещо відстороненим поглядом. I, насамкінець, усвідомлення ролі утопії дає можливість краще зрозуміти значення різноманітних теорій соціальних змін, зокрема й тих, що проголошують настання постіндустріального суспільства. 


\section{Постіндустріальне суспільство як утопія та ідеологія}

Про можливість завершення епохи індустріалізму почали замислюватися ще наприкінці XIX ст., коли з'явилися перші утопії та дистопії, в яких викриваються вади тогочасного «бездушного механізованого суспільства» - наприклад, «Вісті нізвідки» В. Морріса (1890), «Душа людини при соціалізмі» О. Вайлда (1891) чи «Париж у XX столітті» Ж. Верна (1863). Читаючи ці твори, ми розуміємо, що в них зовсім не йдеться про варіанти покращення існуючої індустріальної цивілізації за допомогою подальшого іiі удосконалення, а про пропозиції перевести іiі на цілком відмінні засади і принципи. Значно пізніше побачили світ праці, зокрема «Третя хвиля» Е. Тоффлера (1980) чи «Мегатренди» Дж. Нейсбіта (1982), в яких прийдешня постіндустріальна епоха зображується у вигляді покращеного індустріалізму, який є тоншим, гнучкішим, барвистішим, зорієнтованим на комфорт людини та задоволення іii нестримних бажань.

Підсумовуючи різноманітні теорії постіндустріалізму [25] у теперішній час, можна умовно розділити їх на дві групи [19]. Перші - $є$ явно антиіндустріальними, спрямованими на подолання індустріалізму. Їхні автори вважають його викривленням, хибним шляхом для людства, який веде до катастрофи. Натомість вони пропонують повернення до цивілізації, що схожа на аграрну, а також започаткування справжньої децентралізації і життя у гармонії з природою. Така позиція вперше концептуалізована у працях мислителів, котрих вважають авторами терміна «постіндустріалізм» (А. Кумарасвамі та А. Пенті) у 1910-х роках. Зокрема, А. Кумарасвамі стверджує, що індустріальна система абсолютно не підходить для життя вільної людини: вона жертвує якістю заради кількості, убиває мистецтво і творчість, механізує життя та перетворює людей на тварин $[18$, с. 116,156$]$. А. Пенті вважає індустріальну людину жертвою системи, в якої атрофованими стають людські здібності, вона зведена до рівня автоматів. Надрозподіл праці та науковий менеджмент перетворює іiі на набір фрагментів та розкладає іï духовне, моральне і фізичне життя [21, с. 57]. Постіндустріальним ідеалом обох авторів є суспільство, де панують духовні цінності та повага до великих культурних традицій минулого, а 
люди займаються, здебільшого, ремісницькою творчою працею. Цей варіант постіндустріалізму є безпосереднім спадкоємцем утопії, описаної у творах В. Морріса та Дж. Раскіна. Така утопія є оберненою в минуле, ідеалізує його та відкидає будь-які концепції, базовані на лінеарному метапатерні прогресу (ілюстративними $є$ слова А. Пенті про те, що «майбутнє можна віднайти лише у минулому» і що минуле є важливішим за теперішнє, оскільки «великі культурні традиції походять із минулого» [21, с. 137-138]).

Інша група постіндустріальних теорій, основні з яких створені у 1970-1980 рр., хоча й пов'язана з критикою індустріалізму, проте розглядає його як обов'язкову сходинку на шляху до кращого майбутнього. Автори цих теорій зосереджують увагу на процесах становлення сервісної економіки та використання потенціалу нових знань і технологій. Чимало з них схильні ідеалізувати уже не минуле, а майбутнє, а їхня картина світу часто-густо вибудовується на протиставленні «грубого і потворного» індустріалізму із привабливим та різнобарвним світом постіндустріальної епохи [26]. Надійним базисом для цього слугує лінеарний метапатерн, за яким суспільство постійно рухається у напряму прогресу під впливом зростаючої раціоналізації та швидкого приросту знань. Ілюстративною щодо цього є позиція Е. Тоффлера, який надзвичайно жорстко викриває вади індустріалізму, проте водночас застерігає, що він аж ніяк не має наміру прославляти умови життя у традиційному суспільстві, котре, на його думку, було ще гіршим (при цьому посилаючись на праці 3 промовистими назвами: «Вік агонії» Г. Вільямса та «Смерть, хвороба і голод у доіндустріальній Англії» Л. Кларксона) [13, с. 110].

Постіндустріальні теорії, що входять до другої групи, уже не схожі в усіх своїх частинах на чисті утопії. Їхнє наповнення $є$ дуже різнорідним, а самі їхні автори, зазвичай, намагаються дистанціюватися від утопії та надати своїм витворам рис наукової теорії та усебічно обгрунтованого прогнозу, що, з-поміж іншого, може служити і надійною основою для формування політики та прийняття стратегічних рішень. Зважаючи на це, можна стверджувати, що у межах постіндустріальних теорій 1960-1980 рр. (у різних пропорціях, якщо розглядати різні праці [27]) поєднано три складові: 1) критичний аналіз дійсності - частина, що є найближчою до нау38

Institute of Philosophy of H. S. Skovoroda of NAS of Ukraine 
ки; 2) образи майбутнього, які дуже схожі на утопію; 3) твердження та висновки, що є явно ідеологічними.

Що стосується першого, то цей елемент, на думку багатьох критиків, $є$ безперечно найкращою частиною праць видатних теоретиків-постіндустріалістів $[15$, с. 60$]$. Маючи у своєму розпорядженні значні наукові напрацювання, котрі стосуються досліджень індустріальних явищ та процесів (починаючи від Т. Веблена і закінчуючи Р. Ароном), вони вдало систематизують наявний матеріал, відзначають довгострокові тренди, виокремлюють ознаки та детально описують вади і проблеми, властиві розвинутому індустріалізму.

Про присутність елементів утопій у теоріях постіндустріального суспільства можна говорити, покладаючись на такі аргументи. По-перше, їхні автори постійно ведуть діалог з утопією, включаючи як прямі твердження про визнання чи заперечення приналежності своїх творів до утопічного жанру [28], так і більш завуальовані зв'язки з кількастолітньою утопічною традицією (детальніше про які йтиметься далі). По-друге, усі постіндустріалісти твердять про розрив плавного плину історії, іншими словами, про значну дистанцію між індустріальним минулим та постіндустріальним майбутнім, враховуючи багато ключових аспектів, а дистанціювання від реальності є важливою ознакою утопії [29]. До прикладу, Д. Белл вважає, що постіндустріальне суспільство втілює цілком «новий принцип соціально-технологічної організації і новий спосіб життя», та впевнений у революційних перетвореннях, які торкнуться практично усіх аспектів людського існування $[1$, c. CIX]. Е. Тоффлер говорить про «радикальну зміну напряму» $\mathrm{i}$ «цілковите перетворення, принаймні не менш революційне, ніж те, яке принесла із собою індустріальна цивілізація 300 років тому», та передбачає «суперборотьбу завтрашнього дня» між прихильниками старого і тими, хто готовий іти вперед [13, с. 310, 386]. Потретє, у низці праць, що присвячені постіндустріальному суспільству, воно описане надмірно емоційно, пафосно й однобоко. Перед читачем постає чорно-біла картина реальності, де минула система $\epsilon$ поганою, похмурою, бездушною, викривленою, занадто складною, такою, що заплуталася у власних застарілих принципах і розвалюється прямо на очах. Водночас, постіндустріальні образи є приваб- 
ливими, райдужними, гармонійними та на диво простими і життєздатними.

Найкращим свідченням ідеологічності постіндустріалізму є те, що деякі його складові були легко сприйняті домінантною політико-економічною системою та використані для іiї оновлення і посилення. Так трапилося, не останньою чергою, завдяки багатьом спільним рисам постіндустріальних теорій із індустріальними (включаючи базові ідеї раціональності та прогресу), а також тому, що індустріалізм у середині XX ст. уже практично вичерпав свій потенціал як джерело привабливих образів, котрі скеровують і надихають на дії. Зіштовхнувшись із розчаруванням та зневірою мас $\mathrm{i}$ загальною зміною середовища, капіталізм був просто змушений «скинути шкіру» індустріалізму та виростити нову на основі адаптованих теорій постіндустріального суспільства. Однак при цьому змінилася лише форма, а не сутність, найкращим доказом чого $\epsilon$ невирішені проблеми у сферах, де очікуваними були революційні зміни і перетворення. Усе сказане, насамперед, стосується праці та освіти. Наприклад, індустріальна теорія управління трудовими ресурсами, більш відома як тейлоризм, загалом зберігає у сьогоднішньому світі високу актуальність (притаманним теперішньому часу $\epsilon$ осмислення проблем «цифрового тейлоризму», який поставив собі на службу досягнення нових технологій для забезпечення ефективнішого контролю за працівниками і маніпуляції ними, або ж «нового тейлоризму», що переріс вузькі рамки управління працею та поширився на дозвілля, освіту, політику). Крім того, навряд чи хтось наважиться стверджувати, що суспільство вже наблизилося до вирішення давніх індустріальних проблем відчуження та дегуманізації. Щодо освіти, то тут достатньо згадати про іiі подальшу переорієнтацію у бік потреб економічної системи та законів ринку. Як і iї попередник, постіндустріальна ідеологія підносить одні сфери зайнятості й одночасно опускає інші, забезпечуючи таким чином невпинне зростання економіки [24, с. 2]. Усе це супроводжується поширенням поглядів, близьких до технологічного детермінізму, та укоріненням переконання про безальтернативність обраного цивілізаційного шляху [6]. 


\section{Постіндустріальні ілюзї}

Для того, щоб краще зрозуміти суперечливу сутність постіндустріалізму, детальніше розглянемо його найвиразніші утопічні елементи, зокрема ті, що стосуються сфери цінностей, а також освіти, економіки та політики. Перш за все, члени постіндустріального суспільства, на думку його теоретиків, повинні відмовитися від матеріальних цінностей, втратити інтерес до заробляння грошей і зосередитися на самовдосконаленні, освіті та значущих для своєї спільноти справах. Відзначимо, що йдеться про постматеріалізм не у значенні переходу від споживання товарів до споживання послуг (як це, зазвичай, зображає постіндустріальна ідеологія), а про відмову від споживацьких орієнтацій взагалі. Наприклад, у майбутньому Е. Тоффлера люди Третьої хвилі долають внутрішній розкол на виробників і споживачів (який вважається чи не головною причиною їхніх проблем, включаючи відчуження, механізацію та нестачу часу), знаходять нову рівновагу у житті та перетворюються на надзвичайно розвинені й унікальні особистості - представників «простої і гордої раси» [13, с. 345]. У минуле відходять ринкові орієнтації, поступаючись ідеалам взаємодопомоги та добровільної співпраці.

Обов'язковою передумовою таких змін, очевидно, повинен бути загальний високий достаток. Людям більше не потрібно буде працювати заради грошей. Г. Кан ще у 1967 р. прогнозує ерозію цінностей, орієнтованих на працю, здобутки, прогрес, та передбачає суспільне ставлення до відданих роботі індивідуумів як до небезпечних і деструктивних неврастеніків чи егоїстичних маніяків [5, с. 332; 31]. Й. Масуда твердить про повне звільнення людей від обов'язкової для забезпечення життя праці [20, с. 63]. Е. Тоффлер описує спільну і радісну працю майбутнього в оновленій сім'ї чи «електронному котеджі», яка буде натхненною, творчою та схожою на гру джазових імпровізаторів [13, с. 183, 340]. Людська енергія, котру раніше з'їдав ринок та монструозні бюрократичні інституції, буде спрямована на мистецтво, науку, духовність, громадські справи, що спричинить фантастичні успіхи в усіх цих сфе$\operatorname{pax}[13$, с. 257$]$.

Для більшої переконливості Й. Масуда вибудовує два різні циклічні патерни задоволення потреб людини: 1) матеріального 
споживання, властивий індустріальній епосі, та 2) досягнення мети, який він приписує майбутньому інформаційному суспільству. Для останнього притаманними є орієнтація не на індивідуальні, а на спільні для общини цілі, а також добровільна участь, активна співпраця, самоконтроль учасників [20, с. 127, 135]. Простіше кажучи, люди раптово перестануть дбати про задоволення своїх потреб, які, як відомо, безмежні та постійно зростають, тим самим прирікши глобальну ринкову економіку на повний крах, і займуться тотальним волонтерством та вдосконаленням власної «когнітивної креативності» [20, с. 147].

Подібно до цього, суспільство Третьої хвилі Е. Тоффлера долає розкол між виробництвом і споживанням, у такий спосіб здійснюючи демаркетизацію, і зосереджує «об'єднане виробництвоспоживання» у межах децентралізованих спільнот та нових сімей [13, с. 247]. У Д. Белла вдосконалена постіндустріальна система починає обліковувати не лише економічні, а й так звані безкоштовні блага. Вона відмовляється від орієнтації на економічне зростання та встановлює новий баланс між особистим і суспільним [1, с. 378]. Зменшення ролі ринку у його варіанті майбутнього компенсується зростанням державного впливу, політичний тип прийняття рішень приходить на зміну ринковому, а соціальним механізмам нового комунального суспільства краще вдається забезпечити розподіл благ та раціональний вибір на користь усіх [1, c. 403].

Зрозуміло, що і через 50 років після появи згаданих постіндустріальних теорій пошук у реальності чогось подібного до описаних образів $є$ непростим завданням. Водночас, віднайти зв'язок цих образів з утопіями минулих часів можна без жодних проблем. Про суспільство, яке відмовилося від матеріальних утіх заради духовного та інтелектуального вдосконалення, твердить сам автор терміна утопія Т. Мор ще пів тисячоліття тому. Головна мета суспільного ладу його Утопії - «наскільки це дозволяють суспільні потреби, позбавити громадян тілесного рабства, вивільнивши їм якнайбільше часу для духовної свободи й освіти» [9, с. 62] (для порівняння - постіндустріальні утопісти вважають, що згадане рабство зникне само собою еволюційним шляхом і докладати особливих зусиль не потрібно). Очевидно, що за відсутності у часи 
Т. Мора індустріальної машини для невпинного продукування споживчих благ досягнення цієї мети повинно було супроводжуватися спрощенням, уніфікацією і раціоналізацією життя (усі матеріальні об’єкти в Утопії, включаючи побутові речі, будинки, міста, $є$ однаковими, простими і зручними). Натомість постіндустріалісти, маючи у розпорядженні суспільства таку машину, сподіваються на швидке його «перенасичення» споживанням, що автоматично спричинить перехід на вищу стадію [32].

Починаючи з XVI ст. ідеї постматеріалізму, зникнення ринку, раціонального виробництва і споживання можна зустріти у багатьох утопіях. Уже в індустріальні часи подібні речі у своєму утопічному проекті описує видатний письменник-фантаст Г. Веллс такими словами: «Людина майбутнього не може бути матеріалістом, оскільки усе іiі життя буде безупинним стремлінням до вдосконалення духу» [14]. Постіндустріальні ідеї про працю також аж ніяк не варто вважати новими. Про заміну рутинної праці машинами та про вивільнення часу людини для творчого й наукового розвитку говорить ще К. Маркс [8]. У антиіндустріальній утопії В. Морріса, яка надихала перших постіндустріалістів А. Пенті та А. Кумарасвамі, світовий ринок та індустріальні машини вважаються головними коренями суспільного зла, а творча реміснича праця, якою зайнялися усі люди, є не лише приємною і радісною, а й надає сенс існуванню та різносторонньо розвиває особистість [10, с. 93] (надзвичайно схожі фрагменти про зникнення потворного світового ринку та повернення до домашнього виробництва на зразок того, що було основою традиційного суспільства, знаходимо й у Е. Тоффлера $[13$, с. 255, 299]). Отож, зовсім різні утопії доіндустріальної та індустріальної епох сформовані навколо тих самих цінностей самовдосконалення та самореалізації (зокрема через активну добровільну участь у справах спільноти), про які твердять теоретики постіндустріалізму [33].

Іншим важливим елементом постіндустріальної утопії $\epsilon$ знання, яким відводиться фундаментальна роль. На думку Д. Белла, постіндустріальне суспільство неодмінно буде знаннєвим суспільством, що означатиме як високий (можливо, і найвищий) суспільний статус науковців, так і зорієнтованість усього суспільства на отримання і примноження знань [34]. Усе це науковець опи- 
сує у дуже утопічному стилі. Він твердить про харизматичне наукове співтовариство («невидимий коледж», що протиставляється бюрократичним науково-технічним організаціям), яке здатне породити нову ідеологію суспільства - «символ віри, що проголошує нормою неупереджене знання». Головним суперником на шляху утвердження такої ідеології стануть існуючі бюрократичні та технологічні реалії, захищені старою політичною системою (це один iз проявів прогнозованого ним конфлікту між елітаризмом і популізмом).

Видатні науковці, які присвятили своє життя примноженню знань, набувають у Д. Белла статусу справжніх пророків нової епохи: «Харизматичний аспект науки надає наліт «святості» способу життя іiі служителів» [1, с. 512]. Тому зовсім не дивно, що основною інституцією постіндустріального суспільства у його теорії стає університет, який здатний породити нову еліту для суспільства і стати джерелом нових суспільних цінностей та норм. На думку А. Турена, «університет сьогодні стає привілейованим центром опозиції до технократії та пов'язаних із нею сил» і покликаний не продукувати функціонерів та спеціалістів, а виховувати людей, що здатні критично оцінити суспільні порядки [23, с. 12-14]. Отже, університети та науково-дослідницькі центри мають стати тими осередками, де проходить відбір кадрів для нового політичного правління у постіндустріальному суспільстві, яке побудоване за принципами меритократії. Згідно $з$ теорією Д. Белла, лише найдостойніші і найвидатніші науковці та спеціалісти будуть переміщені меритократичними механізмами на саму вершину, оскільки ніхто інший не справиться $з$ управлінням складними постіндустріальними процесами. При цьому дослідник чітко розділяє технократію і меритократію. Технократичний принцип притаманний, насамперед, індустріалізму (це переконливо доводять, 3-поміж іншого, праці А. Сен-Сімона, Т. Веблена, П. Друкера). Його недоліком є те, що він зводить багатогранні суспільні відносини до технологічної ефективності, і через це не може забезпечити адекватне правління у суспільстві, а лише здатен виконувати функції допуску до системи. Натомість, справжній меритократичний відбір на вищих щаблях влади повинен здійснюватися у межах вузьких знаннєвих середовищ на основі оцінювання особистих досягнень, репутації та ав44

Institute of Philosophy of H. S. Skovoroda of NAS of Ukraine 
торитету конкретного науковця чи спеціаліста [1, с. 611]. На відміну від утопії Д. Белла, постіндустріальна ідеологія не схильна привертати увагу до названих відмінностей між технократією і меритократією.

У суспільстві, що «поклоняється» знанням та науці, не випадково на перші ролі повинна вийти освіта. У різноманітних концепціях вона стає справжнім сенсом життя для постіндустріальної людини, поряд зі служінням суспільству на волонтерських засадах. Наприклад, в інформаційному суспільстві Й. Масуди люди постійно здобувають нові знання, здебільшого поза межами формальних інституцій. Вони надзвичайно схильні до самоосвіти, а реалізовувати це прагнення їм допомагають технологічні новації [20, с. 67]. Відому постіндустріальну концепцію «звільнення від шкіл» розвиває I. Ілліч, який пропонує систему кредиту на навчання, що його отримує кожна людина при народженні та може використовувати протягом усього свого життя [3, с. 89]. Загалом для постіндустріальних утопістів освіта майбутнього є осмисленою, глибокою, творчою, радісною, диверсифікованою, поєднаною 3 практичною діяльністю та спрямованою на гармонійний розвиток особистості.

Коротко відзначимо схожі з постіндустріальними ідеї у західній утопічній думці минулого. Про шкідливість навчання під примусом згадує ще Платон: «Жодної науки людині вільнонародженій не треба вивчати рабським способом. Бо труднощі, які тіло долає під примусом, у цілому йому не шкодять, але знання, силоміць нав'язане душі, там ніколи не зостанеться» [11, с. 235]. Систему надзвичайно різносторонньої освіти, що тісно пов'язана 3 практикою та включає i мистецтва, i ремесла, описує Т. Кампанелла [4, с. 140-141]. Поклоніння науці і знанням, котрі ведуть до чудесних технологій, що покращують життя людей, $\epsilon$ головною засадою суспільства «Нової Атлантиди» Ф. Бекона [2]. У сучасніших утопіях дуже схожою до постіндустріальних образів $\epsilon$ деформалізована та деінституціоналізована освіта у творі В. Морріса. Там діти і дорослі навчаються незалежно від будь-якої системи. Вони знають іноземні мови, оскільки їх знають батьки або друзі, досконало володіють різними ремеслами, бо це надає сенсу життя, вивчають історію чи інші дисципліни тому, що вміють читати, мають інтерес до розвитку, а також вільний доступ до 
книжок [10, с. 70]. Меритократія (відмінна від технократії) є основою політичної системи цілої низки відомих утопій, включаючи твори Платона, Т. Кампанелли, Ф. Бекона, в яких лише найкращі, найдостойніші люди, що володіють глибокими і різноманітними знаннями, можуть здобути владу. Це все - лише поодинокі приклади надзвичайно тісних зв'язків постіндустріальної утопії з їі попередниками, що свідчить про намагання соціальних мислителів другої половини XX ст. відродити цей жанр і у такий спосіб надати нове дихання індустріальній цивілізації.

\section{Замість висновків. Втрачена дуща постіндустріальної ymoniï}

Намагаючись охарактеризувати утопію, яка є частиною теорій постіндустріального суспільства, можна виокремити низку іiі загальних ознак. Найпримітнішим $\epsilon$ те, що більшість ії елементів не $є$ чимось надзвичайно свіжим чи новим, а навпаки - повторенням у дещо зміненому вигляді давно відомих ідей, сформульованих у межах соціалістичних та технологічних утопій минулого. Однак, на відміну від останніх, постіндустріальна утопія перетворюється на утопію інерції, а не дії. Вона утверджує погляд на цивілізаційний розвиток як на безальтернативний шлях, відхилення від якого неодмінно означає регрес та занепад [35]. Від окремої людини чи від багатьох людей разом практично нічого не залежить доводиться вибирати між варіантами: «участь у прогресивній постіндустріальній системі на іiі умовах» або ж «життєва невдача i крах». Та більше, того, хто обирає інших шлях, нерідко оголошують людиною минулого і ворогом прогресу [36]. (Зауважимо, що у межах постіндустріальної ідеології минуле $\epsilon$, фактично, синонімом поганого, а майбутнє - хорошого. Утім, це зовсім не означає, що домінантна політико-економічна система $є$ зорієнтованою на майбутнє. Навпаки - вона глибоко вкорінена у теперішньому і намагається розширити його до безкінечності [22, с. 229].)

Згадані особливості постіндустріальної утопії зумовлені, насамперед, тим, що іiі автори намагаються поєднати те, що важко поєднується, а саме - лінеарний метапатерн прогресу з розривом, за яким видніється утопія. Результат виходить суперечливим та не дуже переконливим. Змішування утопічних й ідеологічних компо46

Institute of Philosophy of H. S. Skovoroda of NAS of Ukraine 
нентів та наукового аналізу вводить в оману як читачів, так і самих авторів, які видають бажане за дійсне і дуже передчасно проголошують негайне завершення індустріальної ери та розпад усього, що 3 нею пов'язано. До того ж, постіндустріальна утопія $\epsilon$ несправжньою (псевдоутопія, або ж напівутопія за класифікацією Ф. Полака) і тому не здатна забезпечити радикальний розрив iз минулим, про який наполегливо твердять ії автори. У ній відсутні яскраві естетичні компоненти, новизна і енергетика, що є ознаками кожної впливової утопії (як зазначає Дж. Коутс, для того, щоб бути конкурентоздатними у сьогоднішньому світі, утопії повинні бути такими самими виразними і захоплюючими, як дистопії [17, с. 31]; а останні, з часів О. Гакслі та Дж. Оруела і дотепер [37], залишаються одними з головних символів нашої епохи).

Як наслідок, продовж останніх кількох десятиліть ми стаємо свідками зовсім не реалізації постіндустріальної утопії, а зародження і посилення постіндустріальної ідеології. Про справжній зміст утопії, як іiї описували теоретики постіндустріалізму, уже мало хто пам'ятає, у кращому разі на нього дивляться крізь призму ідеології. Причиною цього, можливо, є те, що система занадто сильна і не допускає альтернатив. Або ж навпаки - утопія занадто слабка і поверхова та не містить у собі достатнього енергетичного заряду, щоб пробудити приспане комфортом, споживчими благами і безкінечною пустою комунікацією суспільство. Якщо ж цивілізація не здатна творити нові утопії і застрягла у теперішньому, тоді, ймовірно, іï «закінчена історія» може бути перезапущена лише під дією масштабних зовнішніх і внутрішніх викликів. Якими можуть бути ці виклики уявити неважко. Достатньо ознайомитися з яскравими дистопіями, що заполонили весь інформаційний простір сучасного постіндустріального суспільства, яке колись давно втратило свою утопію. 


\section{ЛІТЕРАТУРА ТА ПРИМІТКИ}

1. Белл Д. Грядущее постиндустриальное общество. Опыт социального прогнозирования / Перевод с англ. Москва : Academia. 2004. CLXX, $788 \mathrm{c}$.

2. Бэкон Ф. Новая Атлантида // Бэкон Ф. Сочинения. В двух томах. Т. 2. Москва : Мысль. 1978. С. 483-518.

3. Иллич И. Освобождение от школ. Москва : Просвещение. 2006. 108 с.

4. Кампанелла Т. Місто Сонця // Мор Т., Кампанелла Т. Утопія. Місто Сонця. К. : Дніпро, 1988. С. 131-182.

5. Кан Г., Винер А. Год 2000. Основы предположений о предстоящих 33х годах // Впереди XXI век: перспективы, прогнозы, футурологи. Антология современной классической прогностики. 1952-1999. Ред. И. В. Бестужев-Лада. Москва : Academia. 2000. С. 322-336.

6. Лайон Д. Інформаційне суспільство: проблеми та ілюзії. Сучасна зарубіжна соціальна філософія. К., 1996. С. 362-380.

7. Мангайм К. Ідеологія та утопія / Пер. 3 нім. В. Шведа. К. : Дух і Лiтера. 2008. 370 c.

8. Маркс К. Развитие основного капитала как показатель развития капиталистического производства // Маркс К., Енгельс Ф. Полное собрание сочинений. Том 46-2. Москва : Издательство политической литературы, 1969. С. 120-131.

9. Мор Т. Утопія // Мор Т., Кампанелла Т. Утопія. Місто Сонця. К. : Дніпро, 1988. С. 15-114.

10. Моррисъ В. Въсти ниоткуда или эпоха счастья. СПб. : Дъло. 1906. $209 \mathrm{c}$.

11. Платон. Держава. К. : Основи, 2000. 355 с.

12. Рікер П. Ідеологія та утопія. К. : Дух і Літера, 2005. 386 с.

13. Тоффлер Е. Третя хвиля. К. : Вид. дім «Всесвіт». 2000. 480 с.

14. Уэллс Г. Современная утопия. Завтра: Фантастический альманах. 1991. Вып. 1. С. 120-130.

15. Франкел Б. Постіндустріальні утопісти. К. : Ніка-Центр, 2005. 304 с.

16. Bell W. Foundations of Futures Studies: Human Science for a New Era. Vol. 1. History, Purposes, and Knowledge. New Brunswick, NJ : Transaction Publishers, 2009. 368 p.

17. Coates J. Utopia - An Obsolete Concept // Viable Utopian Ideas: Shaping a Better World. New-York : M. E. Sharpe, Inc. 2003. P. 29-34.

18. Coomaraswamy A. The Essential Ananda K. Coomaraswamy. World Wisdom, Inc. 2004. 311 p. 
19. Marien M. The Two Visions of Post-Industrial Society // Futures, 1977, October. P. 415-431.

20. Masuda Y. The Information Society as Post-Industrial Society. Washington : World Future Society, 1981. $171 \mathrm{p}$.

21. Penty A. J. Post-Industrialism. New York : The Macmillan Company, 1922. $157 \mathrm{p}$.

22. Polak F. The Image of the Future. Elsevier, 1973. 319 p.

23. Touraine A. The Post-Industrial Society. Tomorrow's Social History: Classes, Conflicts and Culture in the Programmed Society. Random House, 1971. $244 \mathrm{p}$.

24. Vogt K. The Post-Industrial Society: From Utopia to Ideology // Work, Employment and Society, 2015. P. 1-11.

25. Йдеться про постіндустріалізм у широкому розумінні, тобто про всі описані варіанти суспільного устрою, який прийде на зміну індустріальному ладу, включаючи концепції суспільства під такими назвами, як постіндустріальне, інформаційне, програмоване, мережеве тощо.

26. Це властиво, зокрема, працям Й. Масуди, Е. Тоффлера, Дж. Нейсбіта, частково - Д. Белла.

27. Наприклад, праця «Постіндустріальне суспільство» А. Турена в основному є результатом намагань збалансовано та об'єктивно оцінити становище, в якому опинилася людська цивілізація в останній третині $\mathrm{XX}$ ст., та всебічно охарактеризувати найгостріші актуальні проблеми. Вона знаходиться на достатньо великій віддалі від утопії, хоча не позбавлена окремих утопічних елементів, які, до прикладу, стосуються значної ролі, що іiі нібито відіграватимуть у майбутньому університети, чи передбачень про зменшення значення економічного чинника.

28. Зокрема, Е. Тоффлер заперечує, що його «Третя хвиля» $є$ утопією, оскільки вона нібито розкриває і проблемні аспекти майбутнього устрою, незважаючи на те, що останні у праці описані в десятки разів коротше порівняно з розлогими ілюстраціями переваг життя у «прекрасному новому світі». Він стверджує, що його метою $є$ «практопія» - «ні найкраще, ні найгірше 3 усіх можливих слів, але практичніше й краще від тих, які застосовувалися раніше» [13, с. 317]. Натомість Й. Масуда не приховує, що його «комп’ютопія» належить до утопій. Водночас, він сподівається на швидке ії втілення, оскільки розумні раціональні люди неодмінно повинні прийняти такі рішення, які прокладуть шлях саме до такого майбутнього.

29. Насправді ж, і через півстоліття після появи досліджуваних теорій чимало ключових виділених авторами ознак індустріального ладу можна вдало використати і для характеристики теперішньої цивілізації. 
Переконливим доказом цього є й те, що яскраві індустріальні дистопії, як-от «Прекрасний новий світ» О. Гакслі (1932) чи «Механічне піаніно» К. Воннегута (1952), попри сподівання постіндустріалістів зовсім не втратили своєї актуальності.

30. Із цією метою вона створює та послуговується різноманітними міфами на зразок «знаннєвої праці», «креативних індустрій», незважаючи на те, що вони за своєю суттю можуть бути дискримінаційними щодо людей інших професій.

31. Тут варто відзначити набагато зваженіший погляд Г. Кана на постіндустріальну реальність, включаючи висвітлення ії значних вад, таких як інфантилізація населення і схильність людей до ірраціональної поведінки через їхню надмірну захищеність та втрату ними контакту 3 реальністю. Справжню гостроту цих проблем суспільство починає відчувати аж через 50 років після написання прогнозу, що свідчить про гарну інтуїцію одного з перших професійних футурологів.

32. До честі утопійців Т. Мора, а також персонажів інших утопій того періоду, вони все ж зробили усвідомлений вибір та послідовно втілюють його у життя, а не покладаються на безальтернативну раціональну систему чи «загальний закон суспільного прогресу». Принцип «сам твори свою утопію» $є$ притаманним і ранньому капіталізму, яскравим свідченням чого $є$ усім відомий роман Д. Дефо «Робінзон Крузо».

33. Утім, у наш час зовсім не $\epsilon$ рідкістю підміна самореалізації споживанням дедалі більшої кількості благ (особливо тих, що їх продукує третинний сектор економіки) та безупинною гарячковою активністю у мережах, яка також тісно пов'язана з економічними інтересами. Це відбувається не без впливу постіндустріальної ідеології і $є$ черговою ілюстрацією значної дистанції між нею та постіндустріальною утопією.

34. Зауважимо, що Д. Белл твердить саме про теоретичне знання, а не про важливі для практики технології, які створюються на його основі $[1$, c. 25]. Це важливо пам'ятати, оскільки, на відміну від його концепції, постіндустріальна ідеологія зорієнтована на прикладні технології, які «покращують життя людей вже зараз». Тобто утопія зберігає дистанцію від реальності, тоді як ідеологія міцно вкорінена у ній та мало змінилася у сенсі оцінки ролі технологій порівняно з індустріальними часами.

35. Це змушує людей підлаштовуватися під наперед задані моделі поведінки, які нібито будуть цінитися і приведуть до успіху у світі завтрашнього дня. У наш час усім знайомі науково-популярні передбачення, в яких сформульовано 10 чи 20 компетентностей і навичок, без яких аж 
ніяк не обійтися у майбутньому, або перелік нових професій, освоївши які людина неодмінно стане затребуваною у межах системи.

36. 3 усіх проаналізованих праць найбільше це стосується «Третьої хвилі» Е. Тоффлера.

37. Достатньо згадати популярність сучасних вражаючих уяву кінематографічних дистопій на зразок серіалу «Чорне дзеркало».

\section{REFERENCES}

1. Bell, D. (2004). The Coming of Post-Industrial Society: A Venture in Social Forecasting. Moscow: Academia. [In Russian].

2. Bacon, F. (1978). New Atlantis. In: F. Bacon, Works in Two Volumes. Moscow: Mysl. [In Russian].

3. Illich, I. (2006). Deschooling Society. Moscow: Prosveshcheniye. [In Russian].

4. Campanella, T. (1988). The City of the Sun. In: T. More, T. Campanella, Utopia. The City of the Sun. Kyiv: Dnipro. [In Ukrainian].

5. Kahn, H., Wiener, A. (2000). The Year 2000: A Framework for Speculation on the Next Thirty-Three Years. In: The XXI Century is Ahead: Prospects, Forecasts, Futurists. The Anthology of Modern Classic Forecasting. I. Bestuzhev-Lada (Ed.). Moscow: Academia. [In Russian].

6. Lyon, D. (1996). The Information Society: Issues and Illusions. In: Contemporary Foreign Social Philosophy. Kyiv: Lybid. [In Ukrainian].

7. Mannheim, K. (2008). Ideology and Utopia. Kyiv: Dukh i Litera. [In Ukrainian].

8. Marx, K. (1969). The Development of Fixed Capital as an Indicator of the Development of Capitalist Production. In: K. Marx, F. Engels, Complete Works. [In Russian].

9. $\quad$ More, T. (1988). Utopia. In: T. More, T. Campanella, Utopia. The City of the Sun. Kyiv: Dnipro. [In Ukrainian].

10. Morris, W. (1906). News from Nowhere (or An Epoch of Rest). Saint Petersburg: Delo. [In Russian].

11. Plato (2000). Republic. Kyiv: Osnovy. [In Ukrainian].

12. Riceur, P. (2005). Lectures on Ideology and Utopia. Kyiv: Dukh i Litera. [In Ukrainian].

13. Toffler, A. (2000). The Third Wave. Kyiv: Vsesvit. [In Ukrainian].

14. Wells, H. G. (1991). A Modern Utopia. Tomorrow: Fantastic Almanac. Is. 1, 120-130. [In Russian].

15. Frankel, B. (2005). The Post-Industrial Utopians. Kyiv: Nika-Tsentr. [In Ukrainian]. 
16. Bell, W. (2009). Foundations of Futures Studies: Human Science for a New Era. Vol. 1. History, Purposes, and Knowledge. New Brunswick, NJ: Transaction Publishers.

17. Coates, J. (2003). Utopia - An Obsolete Concept. In: Viable Utopian Ideas: Shaping a Better World. New-York: M. E. Sharpe, Inc. 29-34.

18. Coomaraswamy, A. (2004). The Essential Ananda K. Coomaraswamy. Rama P. Coomaraswamy (Ed.). World Wisdom, Inc.

19. Marien, M. (1977). The Two Visions of Post-Industrial Society. Futures. October. 415-431.

20. Masuda, Y. (1981). The Information Society as Post-Industrial Society. Washington: World Future Society.

21. Penty, A. J. (1922). Post-Industrialism. New York: The Macmillan Company.

22. Polak, F. (1973). The Image of the Future. E. Boulding, (Trans.). Elsevier.

23. Touraine, A. (1971). The Post-Industrial Society. Tomorrow's Social History: Classes, Conflicts and Culture in the Programmed Society. Random House.

24. Vogt, K. (2015). The Post-Industrial Society: From Utopia to Ideology. Work, Employment and Society, 1-11.

\title{
Petro Sukhorolskyi
}

$\mathrm{PhD}$ in International Law, Associate Professor

Department of International Information

Lviv Polytechnic National University

Lviv, Ukraine, e-mail: sukhorolsky@lp.edu.ua

ORCID: https://orcid.org/0000-0002-1689-3283

\section{Utopian Elements of Post-Industrial Theories: Illusions and Contradictions}

\begin{abstract}
Since being developed in the 1970s-1980s, post-industrial theories have maintained their influence on and significance for scientific research, political decision-making, and shaping of ideas about the future which are dominant in society. However, the contradictions underlying these theories and their heterogeneous content are often overlooked. The paper develops an approach which considers post-industrialism to be a combination of critical analysis of social trends of the past, ideological components, as well as images of the future which are obviously utopian. Highlighting utopian elements of the well-known concepts of
\end{abstract} 52

Institute of Philosophy of H. S. Skovoroda of NAS of Ukraine 
post-industrial and information society makes it possible to conclude that they have a close connection with the socialist and technological utopian thought of preindustrial and industrial eras. The main features of post-industrial utopia usually include: rapid rise of post-materialist and post-consumer values, reduction of the role of market regulation, smart management of the production and distribution of economic and non-economic goods, lifelong deinstitutionalized education and self-perfection, the achievement of public goals through the voluntary participation of citizens in various projects, the central role of universities in society, the rise of meritocracy as a rule by leaders with outstanding abilities, knowledge, and experience. The authors of the theories of post-industrial society try to combine their own ideal image of the future, radically different from the industrial reality, with the linear historical pattern and the idea of progress that underlie industrialism. As a result, their utopia becomes superficial, unoriginal, and unconvincing. As according to F. Polak, it is actually pseudo-utopia or semiutopia that does not fulfil the role of utopia, namely to influence the course of history. That is why for the last half-century we are witnessing not the realization of post-industrial utopia but the strengthening of ideology of post-industrialism which is a direct descendant of its industrial predecessor and relies on the same foundations.

Keywords: post-industrialism, information society, utopia, ideology, image of the future, there is no alternative.

\section{Петро Сухорольский}

кандидат юридических наук, доцент, дочент кафедры международной информации, Национальный университет «Львовская политехника»

2. Львов, Украина, e-mail: sukhorolsky@lp.edu.uа

ORCID: https://orcid.org/0000-0002-1689-3283

\section{Утопические элементы постиндустриальных теорий: иллюзии и про- тиворечия}

\section{Аннотация}

Разработанные в 1970-1980 г2. постиндустриальные теории продолжают сохранять свое влияние и значимость для научных исследований, принятия политических решений и формирования доминантных в обществе пред- 
ставлений о будущем. В то же время без внимания часто остаются противоречия, заложенные в основе этих теорий, и их неоднородное содержание. Развитый в статье подход рассматривает постиндустриализм как результат сочетания критического анализа общественньх процессов, характерных для прошлого и настоящего, с идеологическими компонентами и образами будущего, которые имеют явные признаки утопии. Выделение утопических элементов из известных конщепџий постиндустриального и информационного общеества позволяет сделать вывод об их тесной связи с социалистическими и технологическими утопиями доиндустриальной и индустриальной эпох. Главные особенности постиндустриальной утопии обусловлень стремлением ее авторов согласовать свой идеальный образ будущего, радикально отличающийся от индустриальной действительности, с характерными для индустриализма линеарным метапаттерном и идеей безальтернативного прогресса.

Ключевые слова: постиндустриализм, информационное общество, Третья волна, утопия, идеология, образ будущего, безальтернативность. 